\title{
DETERMINAN AKUNTABILITAS PENGELOLAAN KEUANGAN DAERAH PADA ORGANISASI PERANGKAT DAERAH PEMERINTAH PROVINSI PAPUA
}

\author{
ABSTRACT \\ Asrida ${ }^{1}$ \\ mkduncenjurnal@gmail.com \\ Meinarni Asnawi ${ }^{2}$ \\ meinarni.asnawi@gmail.com \\ Syaikhul Fallah ${ }^{3}$ \\ sehufalah@gmail.com
}

The purpose of this research is to examine and analyze the impact of the human resources quality, utilization of information technology, external pressure and presentation of financial report over the accountability of regional financial management the Papua province government. Sample taken from 47 regional working unit organisation (OPD), 2 person from each, total 94 respondents. Sampling method used is purposive sampling. The data collection was done with the direct survey while hypotheses tested empirically use path analisys. The results of this study explained that human resources quality, utilization of information technology, and external pressure directly influence to presentation of OPD's financial report.

Keywords: human resources quality, the use of information technology, external pressure, the presentation of the financial report, accountability

\section{PENDAHULUAN}

Pengelolaan keuangan daerah di era otonomi serta keterbukaan informasi saat ini, sudah di desak menaati elemen akuntabilitas pada layanan publik. Semua itu akan terlaksana dengan baik, apabila tata kelola akuntansi pemerintah sudah berjalan sesuai perintah regulasi. Disamping itu, dapat juga memberikan peluang terhadap peningkatan penyediaan informasi yang handal dan akurat serta berorientasi pada peningkatan tolok ukur kinerja dalam memberikan pelayanan publik yang maksimal (Akbar 2011).

\footnotetext{
${ }^{1}$ Alumni Mahasiswa Magister Keuangan Daerah Universitas Cenderawasih

${ }^{2}$ Staf Dosen Jurusan IImu Akuntansi Fakultas Ekonomi \& Bisnis Universitas Cenderawasih

${ }^{3}$ Staf Dosen Jurusan IImu Akuntansi Fakultas Ekonomi \& Bisnis Universitas Cenderawasih
} 
Upaya reformasi penyajian pelaporan keuangan daerah nampaknya belum dapat dilaksanakan sepenuhnya oleh pemerintah daerah maupun di jajaran Satuan Kerja Perangkat Daerah (SKPD). Kesiapan Sumber Daya Manusia (SDM) daerah umumnya sangat kurang. Di sisi lain, publikasi laporan keuangan oleh pemerintah daerah melalui surat kabar, internet atau cara lain nampaknya belum menjadi hal yang umum bagi sebagian pemerintah daerah. Salah satu upaya untuk mewujudkan good governance adalah dengan meningkatkan transparansi dan akuntabilitas pengelolaan keuangan Negara.

Salah satu faktor yang mendukung akuntabilitas pengelolaan keuangan daerah adalah kualitas sumber daya manusia, Kualitas sumber daya manusia merupakan suatu kemampuan yang dimilki oleh seseorang sehingga dengan kemampuannya yang memadai dalam melaksanakan tugas serta tanggung jawabnya yang telah diembankan kepadanya, dengan adanya bekal pendidikan, pelatihan, serta pengalaman yang cukup banyak (Widodo, 2001 dalam (Ariesta 2013).

Kajian ini memiliki kesamaan dengan (Jadidah 2014) yang juga melihat variabel pengaruh kualitas sumber daya manusia, pemanfaatan teknologi informasi, Pengendalian Internet Akuntansi dan Pengawasan keuangan daerah terhadap Nilai informasi pelaporan keuangan Daerah di Kabupaten Sleman. Hasil penelitian menjelaskan kualitas sumber daya manusia, pengendalian intern akuntansi dan pengawasan keuangan berpengaruh significand an positif terhadap nilai informasi pelaporan keuangan pemerintah daerah.

Selain Faktor Kualitas SDM, faktor yang mampu mempengaruhi akuntabilitas pengelolaan keuangan daerah adalah penyajian laporan keuangan dan pemanfaatan teknologi informasi. (Rohman, 2009 n.d.) menyatakan bahwa sistem akuntansi pemerintahan harus: Menyajikan secara wajar dan mengungkapkan secara lengkap dana dan aktivitas dari unit pemerintah sesuai dengan GAAP; dan menentukan dan membuktikan kesesuaian dengan peraturan keuangan yang terkait dan syarat-syarat 
kontraktual agar laporan keuangan yang disajikan dapat memenuhi harapan pengguna, namun juga Menurut (Jurnali dan Supono 2002) pemanfaatan teknologi informaasi merupakan adanya tingkat integrasi pada pelaksanaan tugas-tugas akuntansi.

Kajian diatas sejalan dengan kajian (Muhammad Azlan 2015) pengaruh kualitas sumber daya manusia, pemanfaatan teknologi informasi, pengendalian intern akuntansi,dan pengawasan keuangan daerah terhadap keandalan laporan keuangan daerah pada SKPD pemerintah kabupaten lombok timur. Hasil kajian menunjukan bahwa bukti adanya pengaruh positif variabel kualitas sumber daya manusia, pemanfaatan teknologi informasi, pengendalian intern akuntansi, dan pengawasan keuangan daerah terhadap keandalan laporan keuangan.

Kajian ini di dukung oleh kajian (Siti Aliyah 2012) pengaruh penyajian laporan keuangan daerah dan aksesibilitas laporan keuangan daerah terhadap transparansi danakuntabilitas pengelolaan keuangan daerah kabupaten jepara.hasil kajian menunjukan bahwa Penyajian laporan keuangan daerah berpengaruh positif dan signifikan terhadap transparansi dan akuntabilitas pengelolaan keuangan daerah, Aksesibilitas laporan keuangan daerah berpengaruh positif dan signifikan terhadap transparansi dan akuntabilitas pengelolaan keuangan daerah,

Faktor terakhir yang mempunyai pengaruh terhadap akuntabilitas Pengelolaan keuangan daerah adalah tekanan eksternal. Tekanan Eksternal dalam hal ini terkait dengan tekanan yang berasal dari luar SKPD seperti peraturan (regulasi), eksekutif, masyarakat, dan sebagainya. (Frumkin dan Galaskiewicz 2004) menyatakan bahwa tekanan eksternal dapat mempengaruhi tingkat kemampuan pemerintahan menjadi lebih rendah, terutama yang terkait dengan penerapan suatu kebijakan maupun prosedur.

Kajian di atas sejalan dengan kajian (Johannes sihaloho 2013). pengaruh tekanan eksternal, ketidakpastian lingkungan dan komitmen manajemen terhadap penerapan transparansi pelaporan keuangan (studi 
pada satuan kerja perangkat daerah pemerintah kabupaten rokan hilir). Hasil kajian menunjukan bahwa Tekanan Eksternal memiliki pengaruh terhadap Penerapan Transparansi Pelaporan Keuangan, Ketidakpastian Lingkungan tidak memiliki pengaruh terhadap Penerapan Transparansi Pelaporan Keuangan, Komitmen Manajemen memiliki pengaruh terhadap Penerapan Transparansi Pelaporan Keuangan.

Namun kajian diatas Bertolak belakang dengan kajian (Ni Wayan Septiani Dewi 2015). pengaruh tekanan eksternal, faktor politik, dan komitmen manajemen terhadap penerapan transparansi pelaporan keuangan (studi kasus pada SKPD kabupaten karangasem). Hasil kajian menunjukan bahwa Tekanan Eksternal tidak berpengaruh secara positif dan signifikan terhadap Penerapan Transparansi Pelaporan Keuangan, Faktor Politik tidak berpengaruh secara positif dan signifikan terhadap Penerapan Transparansi Pelaporan Keuangan

Berdasarkan latar belakang masalah yang telah diuraikan di atas, maka penelitian ini bertujuan untuk menguji dan menganalisisi pengaruh kualitas SDM, pemanfaatan teknologi Informasi, tekanan eksternal secara langsung maupun tidak langsung terhadap penyajian laporan keuangan serta akuntabilitas pengelolaan keuangan daerah.

Teori Institusional (Institutional Theory). Pemikiran yang mendasari teori institusional (Institutional Theory) adalah didasarkan pada pemikiran bahwa untuk bertahan hidup, organisasi harus meyakinkan kepada publik atau masyarakat bahwa organisasi adalah entitas yang sah (legitimate) serta layak untuk didukung (Meyer dan Rowan 1977). Scott (2008) dalam (Villadsen 2011) menjelaskan bahwa teori institusional digunakan untuk menjelaskan tindakan dan pengambilan keputusan dalam organisasi publik.

Teori Stakeholder. Freeman (1984) dalam (Mainardes et al. 2011 2011) menjelaskan Stakeholder theory, bahwa organisasi harus peduli dengan kepentingan stakeholders ketika membuat keputusan strategis. Meskipun setiap peneliti mendefinisikan berbeda tentang Stakeholder theory, 
prinsipnya sama yaitu perusahaan atau organisasi bisnis harus mempertimbangkan kebutuhan, kepentingan, dan pengaruh dari orangorang atau kelompok yang mempengaruhi atau dipengaruhi oleh kebijakan dan operasi (Frederick et al., 1992 dalam (Mainardes et al. 2011)

Akuntabilitas Pengelolaan Keuangan daerah. Akuntabilitas keuangan merupakan pertanggungjawaban mengenai integritas keuangan, pengungkapan, dan ketaatan terhadap peraturan perundanganundangan. Sasaran pertanggungjawaban ini adalah laporan keuangan dan peraturan perundang-undangan yang berlaku mencakup penerimaan, penyimpanan, dan pengeluaran uang oleh instansi pemerintah (LAN dan BPKP 2003).

Pemanfaatan Teknologi Informasi. (Jurnali dan Supono 2002) pemanfaatan teknologi informaasi merupakan adanya tingkat integrasi pada pelaksanaan tugas-tugas akuntansi. Dimana dalam pemanfaatan teknologi informasi meliputi (1) Pengolahan data dan informasi, proses kerja secara elektronik dan sistem manajemen. (2) memanfaatkan kemajuan teknologi informasi sebagai sarana dalam memberikan pelayanan publik sehingga dapat di akses oleh masyarakat luas dengan mudah dan cepat.

Penyajian Laporan Keuangan Daerah. Penyajian laporan keuangan merupakan hal yang sangat penting, menurut (Diamond 2002) pengungkapan atas informasi ini merupakan suatu elemen dasar dari transparansi fiskal dan akuntabilitas. Dalam Pernyataan Standar Akuntansi Pemerintahan (PSAP) No. 1, alinea 49, (Peraturan Pemerintah Nomor 71 Tahun 2010) dinyatakan bahwa neraca mencantumkan sekurang-kurangnya pos-pos berikut: kas dan setara kas; investasi jangka pendek; piutang pajak dan bukan pajak; persediaan; investasi jangka panjang; aset tetap; kewajiban jangka pendek; kewajiban jangka panjang; dan ekuitas dana.

Tekanan Eksternal. Tekanan Eksternal dalam hal ini terkait dengan tekanan yang berasal dari luar SKPD seperti peraturan (regulasi), eksekutif, masyarakat, dan sebagainya. (Frumkin dan Galaskiewicz 2004) menyatakan bahwa tekanan eksternal dapat mempengaruhi tingkat kemampuan pemerintahan menjadi lebih rendah, terutama yang terkait dengan 
penerapan suatu kebijakan maupun prosedur. Adannya tekanan eksternal dapat berakibat pada praktik-praktik SKPD yang hanya bersifat formalitas untuk memperoleh legitimasi. Praktik-praktik yang dimaksud dalam penelitian ini dikhususkan pada penerapan transparansi pelaporan keuangan.

\section{METODE PENELITIAN}

Tehnik analisis dalam penelitian ini menggunakan analisis deskriptif kuantitatif ini merupakan analisis yang mengemukanan tentang data diri responden, yang diperoleh dari jawaban responden melalui kuisioner. Kemudian data yang diperoleh dari jawaban responden atas pertanyaan yang diajukan, selanjutnya dihitung persentase (Nugroho 2011).

\section{HASIL DAN PEMBAHASAN}

Secara statistik, hasil analisis data penelitian menunjukan bahwa kualitas sumberdaya manusia dan pemanfaatan teknologi informasi berpengaruh langsung secara positif dan signifikan terhadap akuntabilitas pengelolaan keuangan daerah SKPD pada Provinsi Papua. Sementara tekanan eksternal juga berpengaruh positif tetapi tidak signifikan terhadap akuntabilitas pengelolaan keuangan daerah SKPD di Provinsi Papua. Hal ini berarti bahwa peningkatan nilai kualitas sumberdaya manusia, pemanfaatan teknologi informasi termasuk tekanan eksternal secara parsial akan diikuti oleh peningkatan akuntabilitas pengelolaan keuangan daerah SKPD pada Provinsi Papua.

Sementara dasar pengambilan keputusan untuk pengujian hipotesis dalam penelitian ini menggunakan uji t dengan tingkat signifikan 5\%. Kriteria pengujiannya adalah; jika t hitung > t tabel maka $\mathrm{HO}$ ditolak dan $\mathrm{Ha}$ diterima. Uji hipotesis lain yang digunakan dalam penelitian ini juga adalah dengan membandingkan nilai $\rho$ probabilitas (sig), dimana jika nilai $\rho$ probabilitas (sig) $<0.05$ (level of significan) maka Ho ditolak dan Ha diterima. Pembahasan selanjutnya akan dibagi dalam pembahasan pengaruh langsung dan pembahasan pengaruh tidak langsung. 
Temuan hasil seperti yang dikemukakan diatas, menunjukan bahwa terori institusional dan teori stakeholders telah terdukung. Artinya bahwa SKPD selaku entitas akuntansi (accounting entity) yang pada dasarnya telah memiliki legitimasi dan layak unutk menjalankan fungsingya untuk melakukan penyajian dan pengelolaan laporan keuangan secara akuntabel pada Provinsi Papua.

Dikatakan terdukung karena pemerintah selalu berusaha untuk menyesuaikan diri pada harapan eksternal dimana kebutuhan, kepentingan, dan pengaruh dari stakeholders yang mempengaruhi atau dipengaruhi oleh penyajian dan laporan keuangan dan akuntabilitas pengelolaan laporan keuangan daerah pada Provinsi Papua.

Hal ini dibuktikan dari adanya upaya-upaya pemerintah dalam mewujudkan tata kelola yang baik (good governance) melalui usaha-usaha meningkatkan transparansi dan akuntabilitas pengelolaan keungan negara. Usaha reformasi keungan negara mencakup bidang peraturan perundangundangan, kelembagaan, sistem, dan peningkatan kualitas sumber daya manusia.

Untuk dapat mencapai good governance diharapkan penyusunan dan penyajian laporan keungan dapat berpedoman pada sebuah standar akuntansi dalam rangka peningkatan kualitas laporan keuangan seperti adanya penerapan (Peraturan Pemerintah Nomor 71 tahun 2010)tentang Pedoman Standar Akuntansi.

Selain itu tuntutan transparansi dan akuntabilitas tidak hanya menjadi kewajiban pemerintah pusat tetapi juga pemerintah daerah sesuai dengan amanat (Undang-undang No. 32 Tahun 2004) mengenai pemerintah daerah (pemda). Pemda melaksanakan transparansi dan akuntabilitas karena kewajiban dan adanya tekanan yang kuat dari pemerintah pusat. Dipertegas oleh (Peraturan Menteri Dalam Negeri Nomor 59 Tahun 2007) tentang Perubahan atas (Peraturan Menteri Dalam Negeri Nomor 13 Tahun 2006) tentang Pedoman Pengelolaan Keuangan Daerah. 
Penerapan (Peraturan Pemerintah Nomor 71 tahun 2010) ini bukan saja menjamin pelaksanaan pengelolaan keuangan melalui prinsip akuntansi dan pelaporan keuangan yang sesuai dengan standar akuntansi pemerintahan (SAP) namun melaluinya maka aka nada banyak manfaat yang akan diperoleh yaitu; penyusunan laporan keungan pun dapat lebih mudah dan cepat dilakukan, penelusuran dan koreksi lebih mudah dideteksi, sehingga informasi yang diperlukan akan mudah terpenuhi. Serta dengan penerapan (Pemerintah Nomor 71 tahun 2010) ini maka Pemerintah Provinsi Papua telah mampu menyediakan laporan keuangan daerah secara lebih baik kepada seluruh stakeholders.

Pengaruh Langsung Kualitas Sumberdaya Manusia Terhadap Penyajian Laporan Keuangan dan Akuntabilitas Pengelolaan Keuangan

Daerah. Variabel kualitas sumberdaya manusia dalam kajian ini terjabarkan dalam 7 pernyataan. Hasil pengujian hipótesis pertama mengungkapkan bahwa Kualitas Sumberdaya Manusia (KSDM) memiliki nilai thitung sebesar 4.627 yang adalah lebih besar dari nilai ttabel yaitu 1.668 (4.627>1.668) dengan koefisien sebesar 0.435 yang berarti bahwa, terima $\mathrm{Ha}$ dan tolak $\mathrm{H} 0$ atau hipotesis diterima. Hasil ini menunjukan bahwa kualitas sumberdaya manusia berpengaruh positif dan signifikan terhadap Penyajian Laporan Keuangan SKPD pada Provinsi Papua.

Hasil analisis menyangkut pengaruh langsung Kualitas Sumberdaya Manusia lainnya adalah terhadap akuntabilitas pengelolaan keuangan daerah. Hasil pengujian mengungkapkan bahwa kualitas sumberdaya manusia memiliki nilai thitung sebesar 2.276 yang adalah lebih besar dari nilai ttabel yaitu $1.668(2.276>1.668)$ dengan koefisien sebesar 0.276 yang berarti bahwa, terima $\mathrm{Ha}$ dan tolak $\mathrm{HO}$ atau hipotesis diterima. Hasil ini menunjukan bahwa kualitas sumberdaya manusia berpengaruh positif dan signifikan terhadap akuntabilitas pengelolaan keuangan daerah SKPD pada Provinsi Papua.

Temuan ini mendukung pendapat Widodo, (2001) dalam (Ariesta, 2013 2013) yang menyatakan bahwa salah satu faktor yang mendukung 
akuntabilitas pengelolaan keuangan daerah adalah kualitas sumberdaya manusia. Menurut Wahyono (2004 dalam Husna, 2013) informasi harus andal sebagai salah satu indikator berkualitasnya suatu informasi. Keterandalan disini menyangkut sumber daya manusia yang menghasilkannya. Sumber daya manusia pengguna sistem dituntut untuk memiliki tingkat keahlian akuntansi yang memadai atau paling tidak memiliki kemauan untuk terus belajar dan mengasah kemampuan dibidang akuntansi (Fadhilla Husna 2013).

Temuan ini diperkuat oleh hasil analisis deskritif yakni distribusi jawaban responden tentang kualitas sumberdaya manusia yang memiliki nilai rata-rata sebesar 3.92 yang berarti bahwa responden cenderung setuju bahwa dukungan kualitas sumberdaya manusia akan memberikan dampak pada penyajian laporan keuangan dan akuntabilitas pelaporan keuangan daerah di Provinsi Papua. Hasil analisis deskriptif juga mengungkapkan bahwa item yang lebih baik dalam menjelaskan variabel ini adalah item ke 3 yang menyatakan bahwa; "sub bagian keuangan/akuntansi memiliki uraian peran dan fungsi yang jelas" dengan rata-rata tertinggi yakni sebesar 4.41.

Fakta ini ini membuktikan bahwa terwujudnya penyajian laporan keuangan dan akuntabilitas pelaporan keuangan daerah secara baik di Provinsi Papua mampu dilakukan melalui baiknya kompetensi pegawai yang dilihat melalui latar belakang pendidikan, serta kesiapan sistim kerja (penataan uraian job description yang baik sehingga menjamin pelaksanaan peran dan fungsi secara tidak tumpang tindih) yang dapat dilihat melalui pelatihan yang diikuti dan ketrampilan pegawai yang semakin meningkat.

Pernyataan ini didasari oleh hasil analisis diskripsi yang menunjukan bahwa indicator pelatihan melalui pernyataan item ke 7 (pelatihan-pelatihan untuk membantu penguasaan dan pengembangan keahlian dalam tugas dilakukan) adalah merupakan item yang paling baik berikutnya dalam menjelaskan pengaruh sumberdaya manusia terhadap penyajian laporan keuangan dan akuntabilitas pengelolaan keuangan daerah SKPD pada Provinsi Papua dengan rata-rata sebesar 4.00. 
Temuan ini secara langsung menggambarkan bahwa kualitas SDM pada SKPD di Provinsi Papua telah memadai atau meliki kompetensi yang cukup karena mampu menyelesaikan tugas penyusunan APBD jauh sebelum waktu yang ditentukan. Hal ini selaras dengan pernyataan hasil Forum Dosen Akuntansi Sektor Publik, (2006) yang menyatakan bahwa kebijakan untuk melakukan akuntansi tidak dapat dilakukan oleh orang (pegawai) yang tidak memiliki pengetahuan di bidang akuntansi (Forum Dosen Akuntansi Sektor Publik, 2006). Oleh karena itu diperlukan sumberdaya manusia yang kompeten sehingga menghasilkan laporan keuangan yang berkualitas dan bernilai informasi (Karmila, Amries Rusli Tanjung, dan Edfan Darlis 2012).

Pengaruh Langsung Pemanfaatan Teknologi Informasi Terhadap Penyajian Laporan Keuangan dan Akuntabilitas Pengelolaan Keuangan

Daerah. Model pengaruh langsung berikutnya adalah pengaruh pemanfaatan teknologi informasi terhadap penyajian laporan keuangan. Hasil analisis deskriptif variabel pemanfaatan teknologi informasi yang terjabarkan melalui 7 pernyataan menunjukan bahwa responden setuju bahwa dukungan pemanfaatan teknologi informasi akan berdampak pada Penyajian laporan keuangan SKPD pada Provinsi Papua.

Hasil analisis diatas didukung oleh hasil analisis regresi yang menunjukan bahwa pemanfaatan teknologi informasi memiliki nilai thitung sebesar 4.598 yang adalah lebih besar dari nilai ttabel yaitu 1.668 (4.598>1.668) dengan koefisien sebesar 0.467 yang berarti bahwa, terima $\mathrm{Ha}$ dan tolak $\mathrm{HO}$ atau hipotesis diterima. Hasil ini menunjukan bahwa pemanfaatan teknologi informasi berpengaruh positif dan signifikan terhadap penyajian laporan keuangan SKPD pada Provinsi Papua.

Hasil analisis lainnya membuktikan bahwa pemanfaatan teknologi informasi berpengaruh positif dan signifikan terhadap penyajian laporan keuangan SKPD pada Provinsi Papua. Hal ini dibuktikan melalui besarnya nilai thitung sebesar 2.150 yang adalah lebih besar dari nilai ttabel yaitu 1.668 $(2.150>1.668)$ dengan tingkat signifikannya sebesar 0.000 yang adalah lebih kecil dari 0.05 . 
Berpengaruhnya pemanfaatan teknologi informasi tetntu saja akan penjadi penting karena kualitas sumberdaya manusia yang memadai, namun jika tidak didukung dengan teknologi informasi belum tentu bisa menghasilkan laporan keuangan yang andal. Sistem akuntansi pemerintah daerah memiliki transaksi yang kompleks dan besar volumenya. Oleh karena itu, pemanfaatan teknologi akan sangat membantu dalam proses pengolahan data transaksi sehingga laporan keuangan yang dihasilkan terbebas dari kesalahan material yang disebabkan oleh human eror Karmila, Amries Rusli Tanjung, dan Edfan Darlis, 2012).

Dengan perkembangan teknologi yang semakin pesat, diharapkan pemerintah dapat meningkatkan kemampuan pengelolaaan keuangan daerah serta dapat menyampaikan informasi keuangan daerah kepada publik. Kewajiban pemanfaatan teknologi informasi oleh pemerintah dan pemerintah daerah diatur dalam Peraturan Pemerintah Nomor 56 tahun 2005 tentang sistem informasi keuangan daerah.

\section{Pengaruh Langsung Tekanan Eksternal Terhadap Penyajian} Laporan Keuangan dan Akuntabilitas Pengelolaan Keuangan Daerah. Pengaruh langsung selanjutnya dalam kajian ini adalah dari tekanan eksternal terhadap penyajian laporan keuangan SKPD di Provinsi Papua. Variabel tekanan eksternal dalam penelitian ini terwakili oleh 6 pernyataan yang berdasarkan análisis deskriptif memiliki mean sebesar sebesar 3.85. Hal ini berarti responden cenderung setuju bahwa dukungan tekanan eksternal akan berdampak pada penyajian laporan keuangan SKPD pada Provinsi Papua.

Hasil analisis inferensial melalui pengujian regresi linier berganda yang menunjukan bahwa tekanan eksternal memiliki nilai thitung sebesar 1.628 yang adalah lebih besar dari nilai ttabel yaitu $1.668(1.628>1.668)$ dengan koefisien sebesar 0.172 yang berarti bahwa, terima $\mathrm{HO}$ dan tolak $\mathrm{Ha}$ atau hipotesis ditolak. Hasil ini menunjukan bahwa tekanan eksternal berpengaruh positif tetapi tidak signifikan terhadap penyajian laporan keuangan SKPD pada Provinsi Papua. 
Hasil análisis lainnya dengan menggunakan análisis regresi linier berganda menyangkut pengaruh tekanan eksternal terhadap akuntabilitas pengelolaan keuangan daerah menunjukan bahwa tekanan eksternal memiliki nilai thitung sebesar 1.719 yang adalah lebih besar dari nilai ttabel yaitu $1.668(1.719>1.668)$ namun besarnya tingkat signifikansinya adalah 0.090 yang adalah lebih besar dari 0.005 maka dapat dikatakan bahwa terima $\mathrm{HO}$ dan tolak $\mathrm{Ha}$ atau hipotesis ditolak. Hasil ini menunjukan bahwa tekanan eksternal berpengaruh positif tetapi tidak signifikan terhadap penyajian laporan keuangan SKPD pada Provinsi Papua.

Pengaruh Langsung Penyajian Laporan Keuangan Terhadap Akuntabilitas Pengelolaan Keuangan Daerah. Pengaruh langsung yang terakhir dalam kajian ini adalah pengaruh penyajian laporan keuangan terhadap akuntabilitas pengelolaan keuangan daerah. Pernyataan menyangkut penyajian laporan keuangan dalam kajian ini terjabarkan dalam 8 pernyataan yang melalui analisis deskriptif diperoleh nilai rata-rata sebesar 4.04. Hal ini berarti responden cenderung sangat setuju dengan seluruh pernyataan tentang penyajian laporan keuangan yang secara tidak langsung berarti bahwa responden cenderung setuju bahwa penyajian laporan keuangan relatif memiliki dampak terhadap akuntabilitas pengelolaan keuangan daerah.

Hasil analisis deskriptif ini juga menerangkan bahwa berpengaruhnya penyajian laporan keuangan terhadap akuntabilitas pengelolaan keuangan daerah lebih disebabkan oleh item penyajian laporan keuangan yang paling akhir (PLK 8) yang menyatakan bahwa; "Informasi yang dihasilkan dalam laporan keuangan SKPD memenuhi kebutuhan para pengguna laporan keuangan" dengan rata-rata tertinggi yakni sebesar 4.15.

Hasil ini terdukung oleh hasil analisis regresi linier berganda yang mengungkapkan bahwa penyajian laporan keuangan memiliki nilai thitung sebesar 4.446 yang adalah lebih besar dari nilai ttabel yaitu 1.668 (4.446>1.668) dengan koefisien sebesar 0.580 dan besarnya nilai signifikansinya sebesar 0.000 yang adalah lebih kecil dibandingkan 0.05 
yang berarti bahwa, terima $\mathrm{Ha}$ dan tolak $\mathrm{H} 0$ atau hipotesis diterima. Hasil ini menunjukan bahwa penyajian laporan keuangan berpengaruh positif dan signifikan terhadap akuntabilitas pengelolaan laporan keuangan SKPD di Provinsi Papua.

Pembahasan Pengaruh Tidak Langsung Kualitas Sumberdaya Manusia, Pemanfaatan Teknologi Informasi dan Tekanan Eksternal Terhadap Akuntabilitas Pengelolaan Keuangan Daerah. Penelitian ini juga menunjukan adanya pengaruh tidak langsung antara pengaruh kualitas sumberdaya manusia dan tekanan eksternal terhadap akuntabilitas pengelolaan keuangan daerah SKPD pada Provinsi Papua melalui atau dengan mediasi penyajian laporan keuangan SKPD pada Provinsi Papua. Namun pengaruh mediasi tersebut ternyata bukanlah merupakan pengaruh yang dominan yang penjelasannya dibawah ini.

Hal ini dibuktikan dari hasil perkalian antara koefisien jalur kualitas sumberdaya manusia terhadap penyajian laporan keuangan dan hasil perkalian antara koefisien jalur kualitas sumberdaya manusia terhadap akuntabilitas pengelolaan keuangan daerah atau ringkasnya $0.276 \times 0.435 \times 0.580=0.069$. Jika hasil tersebut dibandingkan antara koefisien jalur langung kualitas sumberdaya manusia terhadap akuntabilitas pengelolaan keuangan daerah yang sebesar 0.276 , maka besarnya koefisien jalur tidak langsung tadi adalah lebih kecil $(0.069<0.276)$. Sehingga dapat dikatakan bahwa pengaruh kualitas sumberdaya manusia terhadap akuntabilitas pengelolaan keuangan daerah melalui penyajian laporan keuangan bukanlah pengaruh yang dominan.

Temuan yang sama juga terjadi pada besaran pengaruh tidak langsung tekanan eksternal terhadap akuntabilitas pengelolaan keuangan daerah melalui penyajian laporan keuangan. Hasil analisis menunjukan bahwa besarnya koefisien jalur langsung tekanan eksternal terhadap akuntabilitas pengelolaan keuangan daerah (0.580) adalah lebih besar dibandingkan besarnya koefisien jalur tidak langsung sebesar 0.020 melalui penyajian laporan keuangan $(0.580>0.020)$. 
Berdasarkan temuan pada kedua jalur tidak langsung tersebut, maka sekali lagi dapat dikatakan bahwa pengaruh tidak langsung dari kedua jalur diatas bukanlah pengaruh yang dominan karena besarannya lebih kecil dibandingkan jalur langsungnya.

Temuan ini menunjukan bahwa tanpa dimediasi oleh tekanan eksternal, kualitas sumberdaya manusia dan tekanan eksternal tetap akan mempengaruhi akuntabilitas pengelolaan keuangan daerah SKPD pada Provinsi Papua. Namun, pengaruh total sebagai hasil akumulasi dari pengaruh langsung dan tidak langsung dari kedua jalur tersebut tentunya akan semakin mempertinggi tingkat akuntabilitas pengelolaan keuangan daerah SKPD pada Provinsi Papua.

\section{KESIMPULAN}

Kualitas sumber daya manusia terbukti berpengaruh langsung secara positif dan signifikan terhadap penyajian laporan keuangan pada Organisasi Perangkat Daerah (OPD) Pemerintah Provinsi Papua.

Pemanfaatan teknologi informasi terbukti berpengaruh langsung secara positif dan signifikan terhadap penyajian laporan keuangan pada Organisasi Perangkat Daerah (OPD) Pemerintah Provinsi Papua.

Tekanan eksternal terbukti berpengaruh langsung secara positif tetapi tidak signifikan terhadap penyajian laporan keuangan pada Organisasi Perangkat Daerah (OPD) Pemerintah Provinsi Papua.

Kualitas sumberdaya manusia terbukti berpengaruh langsung secara positif dan signifikan terhadap akuntabilitas pengeloaan keuangan daerah pada Organisasi Perangkat Daerah (OPD) maupun secara tidak langsung melalui penyajian laporan keuangan pada Organisasi Perangkat Daerah (OPD) Pemerintah Provinsi Papua.

Pemanfaatan teknologi informasi terbukti berpengaruh langsung secara positif dan signifikan terhadap akuntabilitas pengelolaan keuangan daerah Organisasi Perangkat Daerah (OPD) Pemerintah Provinsi Papua. 
Tekanan eksternal terbukti berpengaruh langsung secara positif tetapi tidak signifikan terhadap akuntabilitas pengeloaan keuangan daerah Organisasi Perangkat Daerah (OPD) maupun secara tidak langsung melalui penyajian laporan keuangan pada Organisasi Perangkat Daerah (OPD) Pemerintah Provinsi Papua.

\section{DAFTAR PUSTAKA}

Aliyah Siti. (2012). Pengaruh Penyajian Laporan Keuangan Daerah Dan Aksesibilitas Laporan Keuangan Daerah Terhadap Transparansi Dan Akuntabilitas Pengelolaan Keuangan Daerah Kabupaten Jepara. Akuntansi \& Auditing Volume, 8/No. 2/Me, 97-189.

Azlan, M., Herwanti, T., \& Pituringsih, E. (2015). Pengaruh Kualitas Sumber Daya Manusia, Pemanfaatan Teknologi Informasi, Pengendalian Intern Akuntansi, dan Pengawasan Keuangan Daerah PAda SKPD Pemerintah Kabupaten Lombok Timur, 3(2), 188-198.

Bahrullah, A. (2002). Fungsi Manajemen Keuangan Daerah.

Fadila, A.(2009). Aksesibilitas, Penyajiandan Penggunaan Informasi Keuangan Daerah (Studipada Kota dan KabupatenTegal). Jurnal Akuntansi. Universitas Negeri Padang.

Frumkin, P., \& Galaskiewicz, J. (2004). Institutional Isomorphism and Public Sector Organizations. Journal Of Public Administration Research and Theory.

Ferdinand, A. (2014). Metode Penelitian Manajemen. Semarang: Badan Penerbit Universitas Diponegoro.

Imam Ghozali. (2005). Aplikasi Analisis Multivariate Dengan SPSS. (B. P. UNDIP, Ed.). Semarang.

Imam Ghozali. (2013). Aplikasi Analisis Multivariate Dengan Program IBM SPSS 21 Update PLS Regresi (7th ed.). Semarang: Universitas Diponegoro.

Johannes Sihaloho. (2013). Pengaruh Tekanan Ekternal, Ketidakpastian Lingkungan dan Komitmen Manajemen Terhadap Penerapan Transparansi Pelaporan Keuangan (Studi Pada Satuan Kerja Perangkat Daerah Pemerintah Kabupaten Rokan Hillir), (1), 1-15.

Jurnali, T., \& Supomo, B. (2002). Pengaruh Faktor-Faktor Kesesuaian Tugas Teknologi dan Pemanfaatan Teknologi Informasi terhadap Kinerja Akuntan Publik, 5(2), 63-77.

Mardiasmo. (20014). Akuntansi Sektor Publik (2nd ed.). Yogyakarta: Andi. Meyer J. W. and B. Rowan. (1997). Institutionalized Organizations: Formal Structure as Myth and Ceremony. American Journal of Sociology, 85, 340-63. 
Rohman. (2009). Aksesibilitas, Penyajiandan Penggunaan Informasi Keuangan Daerah (Studipada Kota dan KabupatenTegal). Jurnal Akuntansi, XIII. No.0, 252-264.

Wayan, N., Dewi, S., Sujana, E., \& Sinarwati, N. K. (2015). KEUANGAN ( Studi Kasus Pada SKPD Kabupaten Karangasem ), 